\title{
PERFORMANCE OF AN AGRICULTURAL DIESEL ENGINE USING DIFFERENTS FUELS
}

Doi:http://dx.doi.org/10.1590/1809-4430-Eng.Agric.v37n1p91-97/2017

\section{GISMAEL F. PERIN ${ }^{*}$, JOSÉ F. SCHLOSSER ${ }^{2}$, LEANDRO GALON ${ }^{3}$, FABRÍCIO A. RODRIGUES ${ }^{2}$, ULISSES G. FRANTZ ${ }^{4}$}

\author{
${ }^{1 *}$ Corresponding author. Universidade Federal da Fronteira do Sul - UFFS/ Erechim - RS, Brasil. E-mail: gismael@uffs.edu.br
}

ABSTRACT: The use of fuels for agricultural Diesel engines cycle, both of mineral origin (Diesel) or vegetable and animal origin (biodiesel) can significantly alter its performance. Therefore, the aim of this study was to quantify the change in torque, power and consumption of agricultural Diesel engine fuel using minerals and vegetables fuels. It was used a tractor power take-off coupled to a magnetic brake dynamometer (for measuring speed and torque for subsequent calculation of power), and a flow meter (for measuring the hourly fuel consumption and specific fuel consumption calculation). Eleven different fuels (S10 mineral diesel with 5\%, 10\%, 15\%, 20\% and 50\% biodiesel and mineral diesel S500 with 5\%,10\%, 15\%, 20\% and 50\% biodiesel, have been used pure biodiesel B100). The results indicate that the increase of biodiesel in mineral diesel reduces torque and power, increases the specific fuel consumption and practically does not change the hourly consumption. This reduction in torque and power occurs with greater intensity in Diesel S10. Additions of $10 \%$ biodiesel in mineral diesel reduces the maximum torque $1.65 \mathrm{Nm}(0.6 \%)$, the maximum power at $0.33 \mathrm{~kW}(0.6 \%)$ and increases the specific fuel consumption of $3.6 \mathrm{~g} \mathrm{kWh}^{-1}$ $(1.3 \%)$.

KEYWORDS: test, dynamometer, tractor, torque, power.

\section{INTRODUCTION}

Agricultural mechanization uses basically Diesel internal combustion engines, which require energy stored in liquid form, as most agricultural operations are carried out in motion, for tractors, harvesters, and self-propelled sprinklers, among others. Currently, much of this fuel is mineral, which is from finite and non-renewable source. Still, there is underway in Brazil a reduction in the sulfur content in mineral diesel that can reach up to $10 \mathrm{mg} \mathrm{L}^{-1}(10 \mathrm{ppm}$ - Diesel S10) and the most widely used in agriculture with $50 \mathrm{ml} \mathrm{L}^{-1}$ (Diesel S500). According to MELILLO et al. (2009) there is a global incentive for the partial substitution of diesel fuel of mineral origin by others from plant and animal origin, commonly called biodiesel. Added to this, the growing concern over environmental pollution and the increase in oil prices has driven the development of research in seeking for renewable fuels (DELALIBERA, 2012).

In Brazil, currently 5\% biodiesel is blended with mineral diesel and government policies point to a higher percentage in the future. The use of biodiesel should aim not to modify the engine while maintaining performance. Nevertheless, it is known that in certain proportions of the two fuels (mineral diesel and biodiesel), there are significant change on engine performance and emission levels. Some studies show that the use of pure biodiesel in vehicle diesel cycle engines reduces the torque and consequently the power generated (MAZIERO et al., 2006; OZSEZEN et al., 2009; BUYUKKAYA, 2010; FIORESE et al., 2011; NIETIEDT et al., 2011) and increases the time consumption and minimum specific consumption (GODESA, et at. 2010; NIETIEDT et al., 2011; REIS et al., 2013; ÖZENER et al., 2014).

However, this information is not presented in a clear way for agricultural diesel engine cycle, and, based on this gap the objective of this study was quantify the torque, power and engine fuel

\footnotetext{
${ }^{2}$ Universidade Federal de Santa Maria - UFSM/ Santa Maria - RS, Brasil

${ }^{3}$ Universidade Federal da Fronteira do Sul - UFFS/ Erechim - RS, Brasil.

${ }^{4}$ UNIPAMPA - Campus Dom Predito/ Dom Pedrito - RS, Brasil.

Received in: 3-26-2015

Accepted in: 8-22-2016
} 
consumption change on agricultural Diesel engine cycle using different fuels such as biodiesel, mineral Diesel S10 and mineral Diesel S500 and their mixtures.

\section{MATERIAL AND METHODS}

The trials were conducted in Agrotecnology Laboratory (Agrotec), part of the Agricultural Machinery Testing Center of Rural Engineering Department of the Federal University of Santa Maria in Santa Maria / RS, Brazil near the geographical coordinates at $29.75^{\circ}$ of South Latitude, and $53.70^{\circ}$ West Longitude, at an altitude of $95 \mathrm{~m}$.

It was used a Massey Ferguson tractor, model MF 4291, 4x2 front wheel assist (FWA) and with cabin built in 2012, with approximately 90 hours of use with 1104A engine - 44T Perkins of four-cylinders Diesel cycle, with a total cylinder capacity of $4400 \mathrm{cc}$, turbocharged, with $77.20 \mathrm{~kW}$ of maximum power (manufacturer information).

Eleven types of fuel were used from three different sources (mineral Diesel S10, mineral Diesel S500 and biodiesel (60\% soybean oil and 40\% animal fat) and their mixtures, as shown in Table 1. In the coding of the fuel used, $\mathrm{S}$ is the amount of sulfur per million parts in the mixture, and $\mathrm{B}$ is the percentage of biodiesel in the mixture.

TABLE 1. Fuels used in the experiment performance.

\begin{tabular}{cccc}
\hline $\begin{array}{c}\text { Percentage of } \\
\text { biodiesel }\end{array}$ & Diesel S10 & Diesel S500 & No mineral diesel \\
\hline $\mathbf{5 \%}$ & S10B5 & S500B5 & \\
$\mathbf{1 0 \%}$ & S10B10 & S500B10 & \\
$\mathbf{1 5 \%}$ & S10B15 & S500B 15 & \\
$\mathbf{2 0 \%}$ & S10B20 & S500B20 & \\
$\mathbf{5 0 \%}$ & S10B50 & S500B50 & \\
$\mathbf{1 0 0 \%}$ & & & B 100 \\
\hline
\end{tabular}

The assay was performed following the NBR 1585 (1996) standard. It was used a dynamometer, commonly called absorption dynamometer, which has a connection point with the motor to be tested. This connection was established through the dynamometer coupled to the power take off (PTO) of the tractor via cardan shaft. It was used an electrical eddy current dynamometer, EGGERS brand, model PT 301 MES (Rendsburg, Germany) with brake capacity of $600 \mathrm{~kW}$ and $7200 \mathrm{Nm}$, which allows working with high-powered tractors.

This dynamometer that the rotation and torque information are measured using sensors and are transferred by Bluetooth communications protocol to a computer on which a computer program of the dynamometer itself performs the receiving, processing and visualization of data and user interface. In addition, the variable power is indirectly achieved with the calculated torque and rotation data collected by the dynamometer sensors.

For the measurement of fuel consumption was used a flow meter EGGERS FM3 which is a device that performs the measurement of the instantaneous fuel consumption. The inlet and return hoses are attached to the flow meter and the suction lines and return flow were inserted into the reservoir; a feed movement was created when the device has been connected. This device is integrated with the computer program that controls the dynamometer. With this, for each rotation where there was torque and rotation collection, the computer program also collects the hourly fuel consumption. The computer program calculates the specific consumption based on the density of the fuel.

The tractor engine remained in heating for a period of 20 minutes. To perform this heating, the engine was accelerated at full speed and after that, the dynamometer exerted a sufficient braking to reduce by $25 \%$ the maximum engine speed. After this heating period, the test began to be 
realized. The dynamometer was configurated to perform data reading at every drop on $50 \mathrm{rpm}$ engine speed, from the first performed collection $(2450 \mathrm{rpm})$.

The fuels were placed in a tractor external container (fuel tank was not used) to facilitate its replacement, however, there was no filtering of the fuel. For the exchange of fuel the engine remained accelerated and load for 5 minutes to consume all the fuel that was in its power system.

Four replications were carried out in sequence of the same fuel without slowing the motor between them. To calculate the power and specific consumer from rotation, torque and time consumption data were necessary to collect the data of atmospheric parameters (temperature, relative humidity and atmospheric pressure) and the density of the fuel at each change.

The density of the fuel is shown in Table 2 and was determined with a precision balance at room temperature prior to the use for dynamometer test. The temperature for determining the fuel density was approximately $22^{\circ} \mathrm{C}$.

TABLE 2. Density of fuels used in experimental performance.

\begin{tabular}{ccc}
\hline Percentage of biodiesel & Diesel S10 $\left(\mathrm{g} \mathrm{kg}^{-1}\right)$ & Diesel S500 $\left(\mathrm{g} \mathrm{kg}^{-1}\right)$ \\
\hline $\mathbf{5 \%}$ & 836 & 832 \\
$\mathbf{1 0 \%}$ & 846 & 844 \\
$\mathbf{1 5 \%}$ & 850 & 845 \\
$\mathbf{2 0 \%}$ & 856 & 847 \\
$\mathbf{5 0 \%}$ & 860 & 858 \\
$\mathbf{1 0 0 \%}$ & & 881 \\
\hline
\end{tabular}

The homogeneity of variance test was performed according to Bartlett and the normality of the residuals by Shapiro-Wilk test. Once these conditions was met it was performed the variance analysis $(\mathrm{p} \leq 0.05)$ to identify differences between fuels. All statistical analyzes on this study were carried with a scheduled routine or integrated by $\mathrm{R}$ Version 3.1.1 (R Development Core Team, 2012) using the Agricolae ((MENDIBURU, 2012) package. In addition, linear regression analysis was performed to quantify the change of engine performance parameters by varying fuel type.

\section{RESULTS AND DISCUSSION}

The higher rotations were discarded (above $2350 \mathrm{rpm}$ ), since they had not homogeneous variances with other rotations, preventing the completion of the variance analysis test. Therefore, the range on speed was from 1250 to $2300 \mathrm{rpm}$. To analyze the occurrence of significant difference between the fuels was applied the Tukey test at 5\% significance after the ANOVA assumptions acceptance. Those results are shown on Table 3.

TABLE 3. Difference between the means for the variables of fuel engine performance.

\begin{tabular}{cccc}
\hline Fuel & $\begin{array}{c}\text { Maximum torque } \\
(\mathbf{N m})\end{array}$ & $\begin{array}{c}\text { Maximum power } \\
(\mathbf{k W})\end{array}$ & $\begin{array}{c}\text { Minimum specific consumption }(\mathbf{g ~ k W} \\
\left.\mathbf{h}^{-\mathbf{1}}\right)\end{array}$ \\
\hline S10B5 & $332.5 \mathrm{a}^{1}$ & $71.3 \mathrm{a}$ & $120.7 \mathrm{~g}$ \\
S10B10 & $328,2 \mathrm{~b}$ & $70,7 \mathrm{~b}$ & $121,1 \mathrm{efg}$ \\
S10B15 & $328.7 \mathrm{~b}$ & $70.8 \mathrm{~b}$ & $118.5 \mathrm{~g}$ \\
S10B20 & $326.7 \mathrm{c}$ & $69.9 \mathrm{~d}$ & $129.7 \mathrm{c}$ \\
S10B50 & $323.0 \mathrm{f}$ & $68.9 \mathrm{f}$ & $132.4 \mathrm{~b}$ \\
S500B5 & $324.7 \mathrm{de}$ & $69.1 \mathrm{f}$ & $125.7 \mathrm{de}$ \\
S500B10 & $326.2 \mathrm{c}$ & $69.8 \mathrm{c}$ & $121.9 \mathrm{fg}$ \\
S500B15 & $325.5 \mathrm{~d}$ & $69.4 \mathrm{de}$ & $123.6 \mathrm{efg}$ \\
S500B20 & $323.7 \mathrm{e}$ & $69.4 \mathrm{e}$ & $123.9 \mathrm{def}$ \\
S500B50 & $321.2 \mathrm{~g}$ & $69.2 \mathrm{f}$ & $126.5 \mathrm{~cd}$ \\
B100 & $313.2 \mathrm{~h}$ & $67.4 \mathrm{~g}$ & $137.5 \mathrm{a}$ \\
\hline
\end{tabular}

${ }^{1}$ Fuels followed by the same letter in the column do not differ by Tukey's test at $\mathrm{p} \leq 0.05$. 
The fuel differed in 8 different groups (letters "a" to "h") to the variable torque (Table 3). The fuel that provided the highest torque (332 Nm) was the S10B5, followed by Diesel S10 with 10\% biodiesel and $15 \%$, which did not differ between them. The lowest torque $(312 \mathrm{Nm})$ was with the $\mathrm{B} 100$. This reduction is a difference of $6 \%$ using B100 compared to B5. The best performances were achieved with the Diesel S10, which is promising since it probably will replace the Diesel S500.

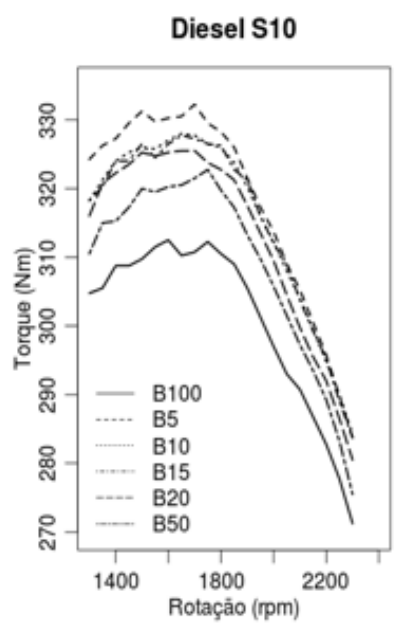

A

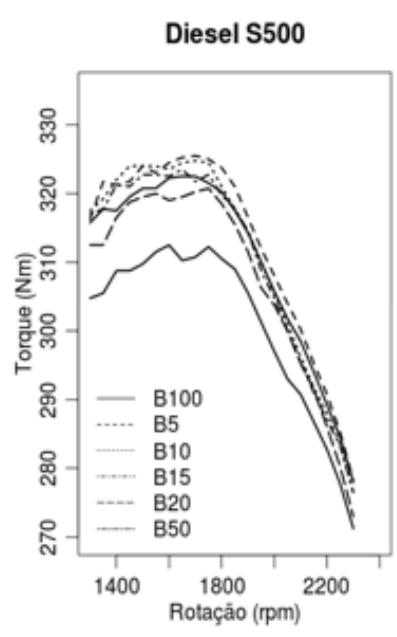

B

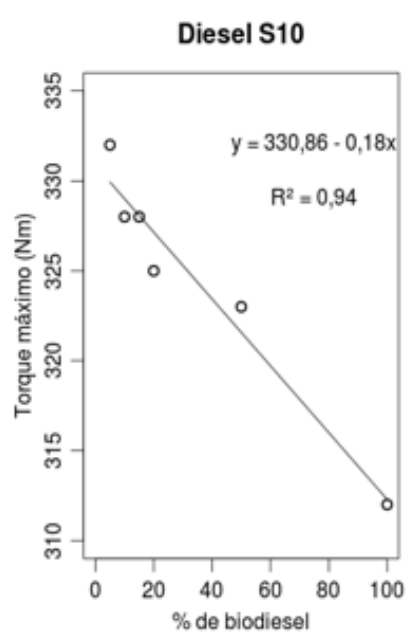

$\mathrm{C}$

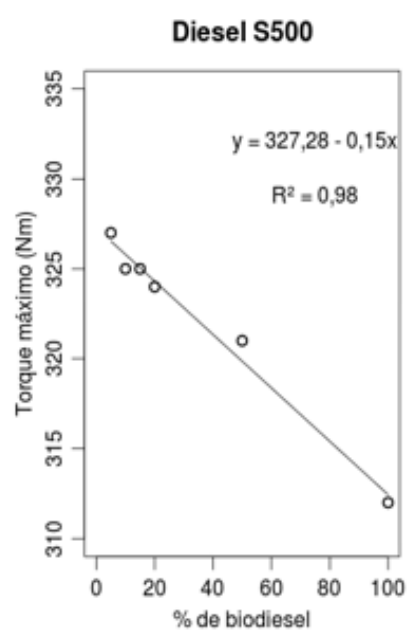

$\mathrm{D}$

FIGURE 1. Torque $(\mathrm{Nm})$ of the engine using various fuels (A and $\mathrm{B}$ ) and behavior of maximum torque as a function of the biodiesel concentration $(\mathrm{C}$ and $\mathrm{D})$.

The maximum torque, on the average of the 5 biodiesel mixtures (blends) with diesel S10 was 327.2 Nm, whereas with diesel S500 was $324.4 \mathrm{Nm}$. This can be seen by the peaks in the curves in Figure 1. In addition, with diesel S500 the curves remain closer, while with the diesel S10, further apart. This greater change in Diesel S10 may be due to the fact that this fuel contains less amount of sulfur than Diesel S500 and thus interferes with greater intensity with the addition of biodiesel. To complement the obtained results for the variable torque with this performance test were generated the linear regression equations (Figure 1 on the right side), with the maximum torque values and their variation with biodiesel increase in the fuel mixture, separating the mineral Diesel fuel (S10 and S500).

It can be seen by examining Figure 1 that with increasing concentration of biodiesel in the mixture the maximum torque of the motor decreases for both Diesel S10, as to the Diesel S500. However, for the Diesel S10, an increase of $10 \%$ biodiesel in the mixture reduces the maximum engine torque at $1.8 \mathrm{Nm}$. As for Diesel S500 this reduction is on the order of $1.5 \mathrm{Nm}$. The smallest reduction on maximum torque when using Diesel S500 was the sulfur in higher quantity in this Diesel and it has fuel properties. Another important result is a reduction of $6.2 \%$ on maximum torque when using B100 compared to B5. FIORESE et al. (2011) found reduction of $4.3 \%$ in these same mixtures. According to the authors, this is due to the lower calorific power in biodiesel. In study by OZSEZEN et al. (2009) found $4.5 \%$ reduction in the maximum torque when the biodiesel concentration was increased in the mixture. BUYUKKAYA (2010) working with pure canola oil (B100) compared to commercial diesel B5 observed a reduction in the maximum torque at $8 \%$ with pure biodiesel in relation to B5. ÖZENER et al. (2014) reported a decrease of up to $4 \%$ on maximum torque with the mixture B50 (soybean biodiesel) compared to pure mineral diesel.

The maximum power (Figure 2) was achieved, regardless of the fuel on $2250 \mathrm{rpm}$ or 2300 $\mathrm{rpm}$. The higher maximum power value was reached with the S10B5 fuel, registering $71.3 \mathrm{~kW}$ at $2300 \mathrm{rpm}$. The worst power performance was achieved with pure biodiesel with $67.4 \mathrm{~kW}$. The absolute difference of maximum power with these two fuels was $3.9 \mathrm{~kW}$ or $5.5 \%$. The same way that torque, it is noticed a minor difference of the power behavior when increasing the biodiesel 
concentration in Diesel S500. It is also possible to observe an increase in power when using Diesel S10 compared with the S500, in biodiesel concentrations B5 to B20 (Figure 2).

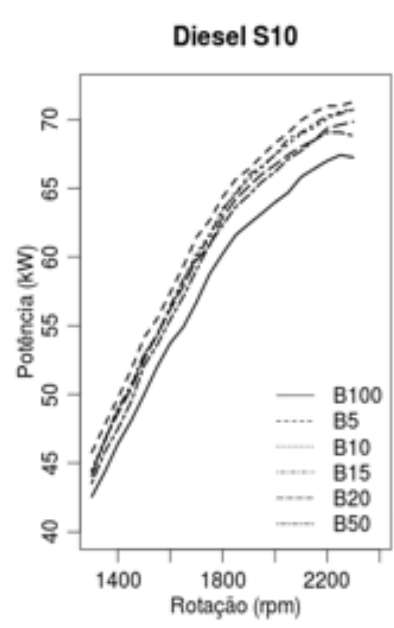

A

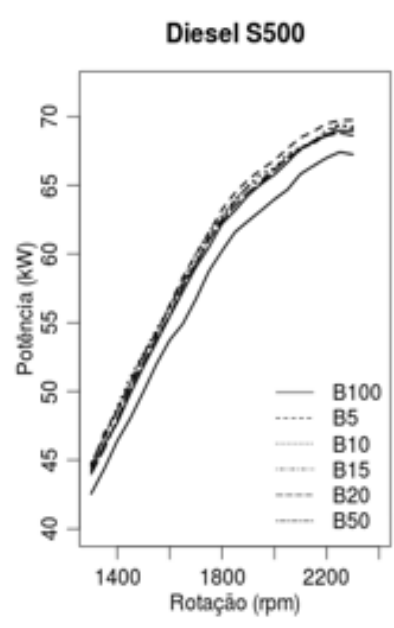

B

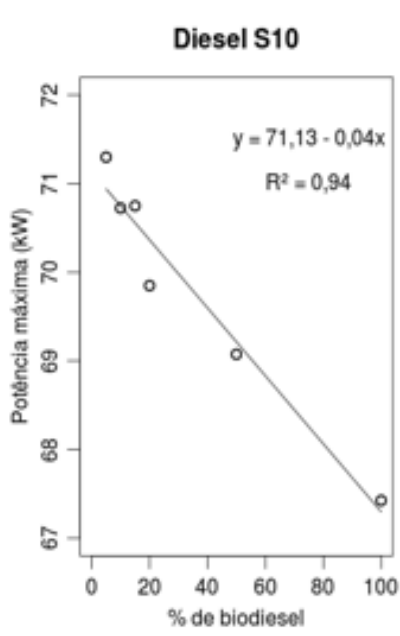

$\mathrm{C}$

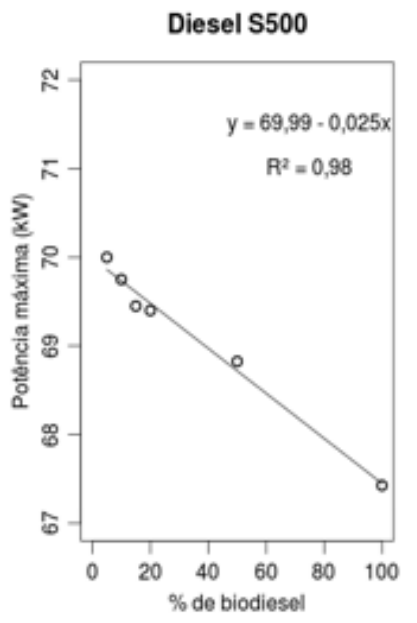

$\mathrm{D}$

FIGURE 2. Power $(\mathrm{kW})$ of the engine using various fuels and behavior of maximum power as a function of the biodiesel concentration.

McCarthy et al. (2011), studying two types of biodiesel, Type A - 80\% of sebum (Cattle, pigs and sheep) and $20 \%$ of methyl ester of canola oil and Type B - $70 \%$ chicken tallow and $30 \%$ of cooking oil residues found that the performance of both biodiesel fuels decreases with increasing in mixing ratio, with decreased at $5 \%$ of torque. The authors attribute this reduction to the lower energy content in biodiesel compared to mineral diesel.

The behavior of maximum power with the addition of biodiesel in the diesel mixture can also be seen in Figure 2. Addition of biodiesel in Diesel S10 reduces the maximum power when compared to the Diesel S500. For each addition of $10 \%$ of the biodiesel in the fuel with 10 ppm of sulfur reduces the maximum power at $0.4 \mathrm{~kW}$. Since, with this same addition, it reduces the maximum power of the Diesel S500 at $0.25 \mathrm{~kW}$. This is because the diesel fuel with lower sulfur content suffers a greater interference when adding biodiesel in the power (Figure 2) and torque parameters (Figure 1).

Another analysis shows that the maximum power with the B100 is $5.5 \%$ less than the maximum power with B5. MAZIERO et al. (2006) found $10 \%$ reduction in maximum power when worked with sunflower biodiesel. Already NIETIEDT et al. (2011) reported a reduction of $2.9 \%$ with B100 in relation to B5. BUYUKKAYA (2010) working with pure canola oil (B100) compared to commercial diesel B5 observed an increase in power of 8.5\% with B5. FIORESE et al. (2011) found reduction of $2.0 \%$ in these same mixtures. According to the authors, this is due to of the lower caloric power in biodiesel.

The B100 fuel showed the increased consumption in all rotations (Figure 3 and Table 3). Based on this, the inference on consumption is as follows: as the consumption time was virtually unchanged since the mixtures were made by volume and not by weight; pure biodiesel generated less torque and less power for the same time consumption. This generates greater spent of fuel per unit power, therefore, higher consumption. In addition, the fuel that had in their mixtures percentages of $20 \%, 50 \%$ and $100 \%$ in biodiesel were those with the highest specific consumption besides the S500B5 fuel (Figure 3). Other fuels had the lowest specific consumption and were not statistically different from each other (letter " $\mathrm{g}$ " in Table 3).

In general, the greater is the proportion of biodiesel mixture in mineral diesel greater is the specific consumption. There was $17 \%$ increase in minimal specific consumption also called power generated per unit of fuel, when using pure biodiesel compared to B5. MAZIERO et al. (2006) found increased, on average, $22 \%$ of the power generated per unit of fuel when worked with 
sunflower biodiesel. GODESA et al. (2010) found an increase in the power generated by fuel unit of $6.5 \%$ with an increase of $50 \%$ of biodiesel. NIETIEDT et al. (2011) reported an increase of $10.9 \%$ with B100 compared to B5. ÖZENER et al. (2014) found an increase up to $9 \%$ of the power generated per unit of fuel with the B50 mixture compared to pure mineral diesel.

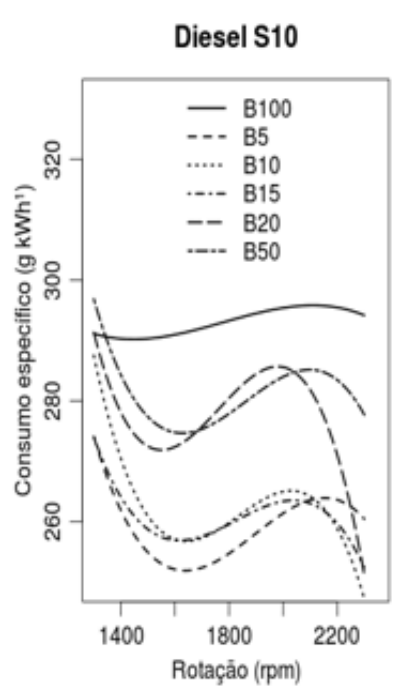

A

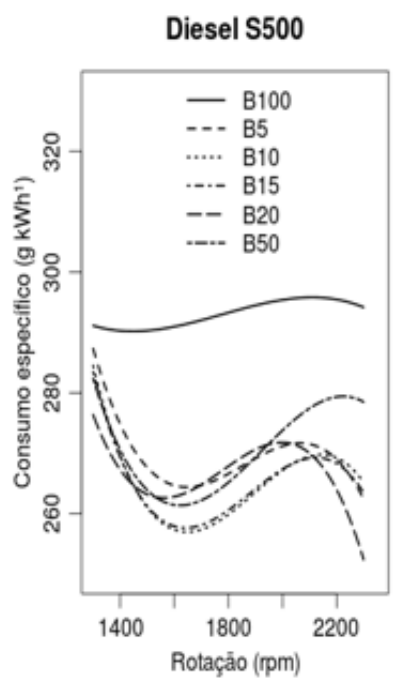

B

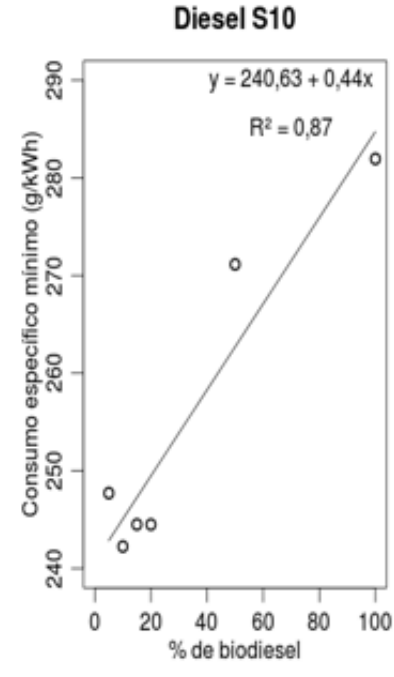

$\mathrm{C}$

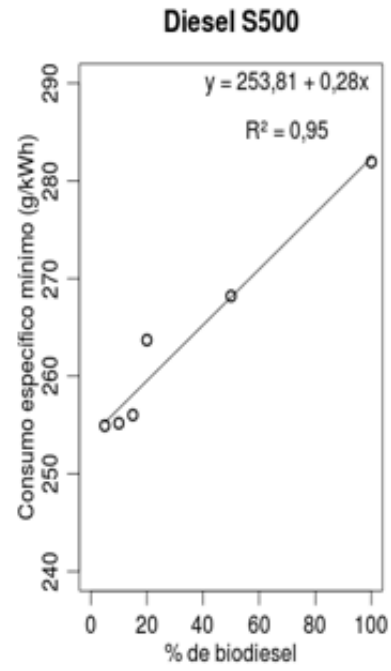

$\mathrm{D}$

FIGURE 3. Specific consumption of the engine using various fuels (A and B) and behavior of minimum specific consumption as a function of the biodiesel concentration $(\mathrm{C}$ and $\mathrm{D})$.

The minimum specific consumption varies from 240 to $280 \mathrm{gkWh}^{-1}$, and the lower specific consumption values have occurred with low biodiesel concentrations in the blends (Figure 3). When using the diesel with $10 \mathrm{ppm}$ of sulfur (S10) with biodiesel concentration mixture smaller than 20\%, it has occurred smaller consumption of all fuel and mixtures analyzed (from 242 to $247 \mathrm{kWh} \mathrm{g}^{-1}$ ). Observing the angular coefficient shown in Figure 3, it was concluded that adding $10 \%$ of biodiesel in the mixture of Diesel S10 results in increased on specific consumption of $4.4 \mathrm{~g} \mathrm{kWh}^{-1}$. For Diesel S500 the increase of $10 \%$ of biodiesel in the mixture with diesel results in a lower specific consumption compared to Diesel S10 of $2.8 \mathrm{~g} \mathrm{kWh}^{-1}$.

The variables torque, power and specific consumption, variables that were performed regression equations for their performance measures, the Diesel S500 always suffered less influence when increased the biodiesel concentration than Diesel S10. This can be explained by the fact that Diesel S500, due it greater amount of sulfur and lower purity degree than Diesel S10, suffers less interference from other components (in case biodiesel).

\section{CONCLUSIONS}

The increased in biodiesel concentration in the mixture with mineral diesel reduces the torque and motor power. This reduction may be up to $5.5 \%$ using $100 \%$ biodiesel fuel.

The addition of biodiesel in Diesel S10 reduces with greater intensity the maximum torque and maximum power when compared to Diesel S500.

The generated power per unit of used fuel was $17 \%$ lower than the use of biodiesel (B100) in relation to Diesel with 5\% of biodiesel (B5).

\section{ACKNOWLEDGEMENTS}

The OLFAR - Food and Energy, by the cession of the biodiesel used in this experiment. To the CNPq for ceding of the Research Fellowship in Productivity. 


\section{REFERENCES}

ABNT NBR ISO 1585. Veículos rodoviários - Código de ensaio de motores - Potência líquida efetiva. Rio de Janeiro, 1996. 9p.

BUYUKKAYA, E. Effects of biodiesel on a DI diesel engine performance, emission and combustion characteristics. Fuel, London, v.89, n.10, p.3099-3105, 2010.

DELALIBERA, H. C.; CAMPOLINA, N.; WEIRICH NETO, P. H., RALISCH, R. Performance of a diesel engine fueled with a preheated blend of soybean oil and petrodiesel. Engenharia Agrícola, Jaboticabal, v.32, n.6, p.1058-1067, 2012.

FIORESE, D. A.; GOMES, L. F. S.; SOUZA, S. M. N. de; DALLMEYER, A. U.; ROMANO, L. N. Metodologia experimental para avaliação de custos de produção e utilização de biodiesel: estudo de caso de quatro ésteres metílicos e óleo diesel comercial. Ciência Rural, Santa Maria, v.41, n.11, p.1921-1926, 2011.

GODESA, T.; JEJ, V.; POJE, T. Characteristics of a tractor engine using mineral and biodiesel fuels blended with rapeseed oil. Scientia Agricola, Piracicaba, v.67, n.5, p.510-516, 2010.

MAZIERO, J. V. G.; CORRÊA, I. M.; TRIELLI, M. A.; BERNARDI, J. A.; D’AGOSTINI, M. F. Avaliação de emissões poluentes de um motor diesel utilizando biodiesel de girassol como combustível. Engenharia na Agricultura, Viçosa, MG, v.14, n.4, p.287-292, 2006.

MCCARTHY, P.; RASUL, M.; MOAZZEM, S. Analysis and comparison of performance and emissions of an internal combustion engine fuelled with petroleum diesel and different biodiesels. Fuel, London, v.90, n.6, p.2147-2157, 2011

MELILlo, J. M.; REILly, J. M.; KICKLIGHTER, D. W.; GURGEL, A. C.; CRONIN, T. W.; PALTSEV. S.; FELZER, B. S.; WANG. X.; SOKOLOV, A. P.; SCHLOSSER, C. A. Indirect emissions from biofuels: how important? Science, Washington, v.326, n.5958, p.1397-1399, 2009.

MENDIBURU, F. de. Agricolae: statistical procedures for agricultural research. 2012. R package version 1.1-1. Disponível em: <http://tarwi.lamolina.edu.pe/ fmendiburu>. Acesso em: 07/01/2014.

NIETIEDT, G. H., SCHLOSSER, J. F., RUSSINI, A., FRANTZ, U. G., RIBAS, R. L., Perfomance evaluation of a direct injection engine using different blends of soybean (Glycine max) methyl biodiesel. Engenharia Agrícola, Jaboticabal, v.31, n.5, p.916-922, 2011.

ÖZENER, O. YÜKSEK, L., ERGENÇ, A. T., ÖZKAN, M. Effects of soybean biodiesel on a DI diesel engine performance, emission and combustion characteristics. Fuel, London, v.115, p.875883, 2014.

OZSEZEN, A. N., CANAKCI, M., TURKCAN, A., SAYIN, C. Performance and combustion characteristics of a DI diesel engine fueled with waste palm oil and canola oil methyl esters. Fuel, London, v.88, n.4, p.629-636, 2009.

R Development Core Team. R: a language and environment for statistical computing. Vienna: $\mathrm{R}$ Foundation for Statistical Computing, 2012.

REIS, E. F. dos, CUNHA, J. P. B., MATEUS, D. L. S., DELMOND, J. G., COUTO, R. F., Desempenho e emissões de um motor-gerador ciclo diesel sob diferentes concentrações de biodiesel de soja. Revista Brasileira de Engenharia Agrícola e Ambiental, Campina Grande, v.17, n.5, p.565-571, 2013. 